International Journal of Linguistics, Literature and Translation

ISSN: 2617-0299 (Online); ISSN: 2708-0099 (Print)

DOI: 10.32996/ijltt

Journal Homepage: www.al-kindipublisher.com/index.php/ijltt

\title{
Listening Activities in EFL Textbooks: An Analytical Study
}

\author{
Khaldoun Ali Al-Janaydeh ${ }^{1} \mathbf{8}(\mathrm{D})$ and Ibrahim Mohammad Deif ${ }^{2} \mathbf{8}$ \\ ${ }^{1}$ Ph.D Graduate, TEFL/ EFL Instructor, Ministry of Education, Ramtha, Jordan \\ ${ }^{2} \mathrm{M} . \mathrm{A}$ in TEFL/ EFL, Instructor, Ministry of Education, Ramtha, Jordan
}

$\triangle$ Corresponding Author: Khaldoun Ali Al-Janaydeh, E-mail: khaldonjanaydeh@gmail.com

\begin{tabular}{|c|c|}
\hline ARTICLE INFORMATION & ABSTRACT \\
\hline $\begin{array}{l}\text { Received: April 08, } 2021 \\
\text { Accepted: May 14, } 2021 \\
\text { Volume: } 4 \\
\text { Issue: } 5 \\
\text { DOI: } 10.32996 / \text { ijllt.2021.4.5.24 }\end{array}$ & $\begin{array}{l}\text { This study aims to analyze the content of the Pupils' Book of Action Pack } 5 \text { in terms of } \\
\text { the listening activities. In this study, the researchers handled these activities using a } \\
\text { content analysis sheet. The study followed the descriptive methodology in analyzing } \\
\text { the content of the listening activities. This study also aims to provide a comprehensive } \\
\text { and clear answer to the extent to which listening activities in Pupil's Book in Action } \\
\text { Pack } 5 \text { are included and frequent and the extent to which listening activities in Action }\end{array}$ \\
\hline KEYWORDS & $\begin{array}{l}\text { Pack } 5 \text { do correspond to the specific outcomes related to listening organiser in the } \\
\text { General Guidelines. The findings showed that the listening activities included in Action }\end{array}$ \\
\hline $\begin{array}{l}\text { Content Analysis, Listening } \\
\text { Activities, Action Pack 5, Jordanian } \\
\text { Curriculum, The Ministry of } \\
\text { Education }\end{array}$ & $\begin{array}{l}\text { Pack } 5 \text { are consistent with the general guidelines of the listening skills. It also showed } \\
\text { that the results of frequency of the listening activities based on the criteria came in } \\
\text { favor of achieving the proficiency level of the organiser. As a result, this research is } \\
\text { beneficial in two areas: first, development of the curricula; and second, planning the } \\
\text { instruction of the listening skill. }\end{array}$ \\
\hline
\end{tabular}

\section{Introduction}

\subsection{Background of the study}

Language is the core of communication. It is the most significant means for transferring needs, feelings, emotions, etc. Whether it is oral or written. Through language, people express their social needs. It enables them to communicate with others easily. Language is a social phenomenon and without language there is no or limited interaction and communication. Thus, communication refers to sending and receiving of a message in which speakers encode the message and the speakers decode that message in order to be understood.

Listening is a natural and receptive skill. It is one of the main language skills in teaching English as a foreign language or a second language. Simply, listening refers to understanding a spoken language (Huei-Chu, 1998). Such skill is unattainable for non-native learners since the surrounding environment of instruction plays a major role in developing this skill. According to Richards $(2008,13)$ "...the main function of listening in second language learning is to facilitate understanding of spoken discourse". A lot of practice is needed where nothing is usually written in front of the learners. Therefore, listening process goes through five-stage: hearing (receiving), understanding (learning), remembering (recalling), evaluating (judging) and responding (answering) (Tygai, 2013). Practically speaking, the English language in the Jordanian context is considered a foreign language. The learners are only exposed to the language in the classroom. Hence, listening is confined to the classroom context.

There are a large group of listening activities used inside the classroom. These activities are varied and differ according to the proficiency levels of the leaners such as listen and say, listen and match, listen and draw, listen and write, listen, read and match, listen and point and so on. Brown (2001) stated different types of listening activities. These activities are: reactive, intensive, responsive, selective, extensive and interactive. Such activities are designed to help learners build their microskills of language at each proficiency level. In addition to this, listening activities should be integrated with the other skills (speaking, reading and writing) since depending on one skill in one lesson is not enough.

\section{K C AL-KINDI CENTER \\ R D FOR RESEARCH AND DEVELOPMENT}

Your gateway to world-class research

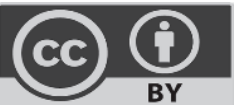

Published by Al-Kindi Center for Research and Development, London, United Kingdom. Copyright (c) the author(s). This open access article is distributed under a Creative Commons Attribution (CC-BY) 4.0 license 
Teaching listening activities are done through systematic procedures and techniques. Therefore, teachers are required to prepare their instruction for such activities and to use the optimal means to teach listening activities based on the most recent and suitable approaches and methods in the field of language teaching. Al-Ghazo and Smadi (2013: 342) stated that "these guidelines include precise and detailed descriptions of the knowledge and skills students are expected to acquire at each grade". Listening activities vary depending on the levels of the learners starting from micro-skills to macro-skills of language. Consequently, it is necessary to include listening activities that are related to learners' life, their environment and culture; such inclusion will help them comprehend the listening activities to improve their communicative competence. Omaggio (2000) stated that alien listening activities might hinder learners' understanding and block their comprehension of such activities.

Action Pack Series is the textbook taught in the governmental Jordanian schools. It is based on the most modern methods of language teaching, combining a topic-based approach with functional language practice, careful attention to grammar and vocabulary and a comprehensive skills syllabus. Therefore, the Ministry of Education set a list of guidelines which concentrate on the main role of foreign language in developing the learners' skills in Jordan. The English language outcomes mentioned in this document are organised into four categories (listening, speaking, reading and writing) which correspond to the four main areas of language use.

During the process of designing this textbook, the listening skill's weight in relation to the other skills is $20 \%$. As a result, each category skill has to be implemented according to the time which suffices that weight. In other words, quantity and quality have to be taken into consideration whether at the level of each category or on the level of the textbook as one unit. Moreover, listening activities are integrated with the other skills in order to fill the gap of occurring in a non-native context and to provide sufficient and adequate practice and enforce it.

\section{Statement of the Data}

Listening activities in Action Pack 5 are of high significance since they present information about varied topics. Therefore, this study explores to what extent the listening activities are included and frequent in Pupil's Book in Action Pack 5 in light of the General Guidelines and Specific Outcomes published by the Ministry of Education in 2006.

\section{Purpose of the Study}

This study aims at analyzing listening activities of the Pupil's Book in Action Pack 5 to identify to what extent the listening activities are included and frequent in Pupil's Book in Action Pack 5. Therefore, the researchers will use the General Guidelines and Specific Outcomes in this case.

\section{Questions of the Study}

The study attempts to answer the following questions:

1. To what extent are listening activities in Pupil's Book in Action Pack 5 included and frequent?

2. To what extent do listening activities in Action Pack 5 correspond to the specific outcomes related to listening organiser in the General Guidelines?

\section{Significance of the Study}

This study is to be conducted in order to analyze the inclusion and frequency of the listening activities in Pupil's Book in Action Pack 5. This study will hopefully be beneficial to EFL teachers, textbook writers, supervisors and educators in the field of planning and developing curricula in the Jordanian context.

\section{Content Analysis}

Content analysis can be one of the best research tools to analyze curricula and textbooks. It plays a vital role in describing the content; it helps teachers, supervisors and educators to discover the strong and weak areas in the textbooks. Al-Ghazo and Smadi (2013) indicated that Content analysis helps to find out to what extent the material or the textbook is appropriate for learners and teachers. In this case, performing content analysis of the English textbooks in Jordan is a necessary technique that requires specific procedures that have to be applied to the text at hand.

Among other definitions, the researchers opted for Holsti's definition as the most comprehensive one. According to Holsti (1969: 14) "content analysis is any technique for making inferences by objectively and systematically identifying characteristics of messages". The purpose of content analysis is to re-describe the content briefly and this description should be objective and accurate. Content analysis can follow either the quantitative approach, the qualitative approach, or a mixed approach of both. Content analysis is utilized to dissect the content of communication, whether it is visual, oral or written to make inferences at the end (Elo and Kyngas, 2007). In this study, the researchers selected the Action Pack for the Fifth Grade as a sample of the English textbooks taught in public schools in Jordan. 


\section{Definitions of Relevant Terms}

7.1. Content Analysis: Elo and Kyngas (2007), content analysis is a method of research which aims at analyzing varied types of different texts. Al-Ghazo and Smadi (2013) defined content analysis as a research technique which is seen as a flexible tool of research that is commonly used in varied different fields of science such as media, curricula, anthropology and evaluation. In this study, it is a procedure carried out to analyze the content of Action Pack 5 for listening activities in order to find out to what extent they correspond to the General Guidelines.

7.2. Action Pack: is an English course for EFL students. It is a course of twelve levels for Jordanian students, leading them from the Basic to the Secondary stages. It is based on the most modern methods of teaching and language, combining a topic-based approach with functional language practice, careful attention to grammar and vocabulary and a comprehensive skills syllabus.

7.3. Action Pack 5: is the fifth level of a twelve-level course for young Jordanian learners of English. It aims at introducing English gradually and efficiently through fun activities, games and songs. Like each level, Action Pack 5 consists of a Pupil's Book, an Audio, an Activity Book and a Teacher's Book.

7.4. Listening activities: According to the Ministry of Education (2015: 15) listening activities "are oral tasks presented or spoken by native speakers of English on the audio. These tasks are varied and have different purposes". These tasks include Listen and read, Listen and answer / Listen, ask and answer, Listen and match, Listen and say and Listen, choose and say/Listen, complete and say.

\section{Literature Review}

Listening activities in Action Pack series are highly significant since they can be rightly considered the basis for the development of speaking. Therefore, Action Pack 5 introduces various listening activities on different topics which are selected appropriately to suit learners' levels of proficiency. These activities should be presented by the teachers through the audio materials (The Ministry of Education, 2014).

Many studies were carried out on EFL textbooks using content analysis as a tool for collecting data in many aspects of language which are vocabulary, grammar, reading, speaking and writing. In this study, the researchers included the most relevant and significant studies related to teaching listening and listening activities in EFL textbooks.

Keban, Muhtar and Zen (2011) analyzed 'English for Kids 3' textbook. The study was carried out to find out to what extent 'English for Kids 3' meets the criteria of good EFL textbook. They used a checklist to analyze the content. The results showed that 60.86 of the textbooks met the criteria.

Manasrah, Al-Sobh and Al-Jabali (2013) analyzed the content of Action Pack 12 in Jordanian schools to find out whether the vocabulary items meet the vocabulary analysis criteria suggested by Celce-Murcia (1991). The results of the study were that the vocabulary items were appropriately used. The results also showed that the vocabulary items are inclusive, the accessibility was excellent, suitable for learners' levels and the distribution is convincing.

Dugassa and Mijena (2014) analyzed the listening lessons in the Student's Book and Teacher's Guide of English in Ethiopia. The study was carried out to find out the design of the listening lessons in the Ninth Grade. The study used content analysis as a research tool for collecting data. They used a checklist adapted from NCLRC (2004) and Lingzhu (2006) to analyse the data. The findings of the study showed that the three listening stages were not properly met in the material evaluated.

Assaly and Igbaria (2014) analyzed the textbook Master Class for Tenth Grade students. The study investigated to what extent the activities in reading and listening activities emphasized high and low-level thinking skills. Content analysis was carried out on reading and listening sections for each unit. The activities were collected and analyzed according to Bloom's Taxonomy. The study found out that 114 activities stressed on cognition levels representing lower order thinking skills, while 59 activities stressed the three higher-order thinking skills.

Mizbani and Calak (2017) analyzed listening and speaking activities of Iranian EFL textbook Prospect 3 for third Grade students. The study investigated in which level of the lower or the higher learning objectives match Bloom's Revised Taxonomy of Cognitive domain. The results indicated that all the activities of listening and speaking match the lower- level of cognitive domain, but they did not match higher-level thinking skills.

Taamneh (2018) analyzed the listening activities of the Pupil's Book in Action Pack 5 (old edition). The study was carried out to determine to what extent the listening activities are included in the first six units in Action Pack 5. Furthermore, the study carried out to investigate to what extent the listening activities in these units meet the Listening Specific Outcomes in the Jordanian Guidelines. To achieve the aim of the study, frequencies and percentages were used. The study revealed that there a variety of 
listening activities presented in Pupil's Book in Action Pack 5. In addition, the findings revealed that there was a strong relationship between listening activities and listening specific outcomes.

Reviewing the previously mentioned studies, the researchers noticed that the listening activities in EFL textbooks need more analysis in the Jordanian textbook Action Pack since it has not been focused upon in research and analysis. This interest in investigating listening activities in Action Pack 5 comes from the importance of teaching and learning listening in the development of productive skills, namely speaking.

\section{Methodology}

In this section, the study presents the procedures which were used to conduct the current analysis, particularly; it describes the content under analysis, criteria, categories, instruments and their validity and reliability.

\subsection{Content}

The material to be analyzed throughout this study is the Pupil's Book of Action Pack 5, adopted for the academic year 2014/2015. This textbook contains eighteen fundamental units divided evenly between two academic semesters.

\subsection{Criteria of Analysis}

- Recognize the different sounds of some consonant alphabet.

- Respond to questions before, during, and after listening.

- Show appreciation to rhymes and songs.

- Use pictures to understand new or unfamiliar words when listening.

- Take notes when listening to remember the main idea.

\subsection{Unit of Analysis}

The unit of analysis of this study is the listening activity itself. In this case, the entire English language Pupil's Book for Grade Five has been used in this content analysis in order to bring pertinent answers and to judge whether the content under analysis includes and matches the criteria (specific outcomes) cited in the guidelines or not.

\subsection{Instrument of Analysis}

The researchers used a content analysis sheet to find out the inclusion and frequency of the listening activities which are represented in Pupil's Book in Action Pack 5 in light of the General Guidelines and General and Specific Outcomes Document.

\subsection{Reliability of the Content Analysis}

To ensure the reliability of the content analysis, the researchers repeated the analysis after two weeks using the same definitions, criteria, categories and units of analysis. The percentage of agreement between the two analyses was $92.6 \%$. This indicates that they were acceptable and reliable.

\section{Findings and Discussions}

The findings and discussions of the analysis are introduced in light of the questions of the study which ask about the inclusion and the presentation of the listening activities in the Pupil's books of Action Pack 5 . In order to answer these questions, the researchers carried out a comprehensive analysis of the content using a content analysis sheet. Frequencies and percentages were used to report the findings of analysis. Table 1 presents the frequencies and the percentages of the listening activities in Action Pack 5 according to the criteria of the guidelines.

Table 1 Represents the Frequency and the Percentage of the Listening Activities in Action Pack 5 according to the Criteria of the Guidelines

\begin{tabular}{llll}
\hline Criteria (Specific Outcomes) & Frequency & Percentages \\
\hline 1. & $\begin{array}{l}\text { Recognize the different sounds of some consonant } \\
\text { alphabet. }\end{array}$ & $\mathbf{8}$ & $\mathbf{1 0 . 5 2 \%}$ \\
2. & $\begin{array}{l}\text { Respond to questions before, during, and after } \\
\text { listening. }\end{array}$ & $\mathbf{3 3}$ & $\mathbf{6 . 6 \%}$ \\
3. Show appreciation to rhymes and songs. & $\mathbf{5}$ & \\
\hline
\end{tabular}




\begin{tabular}{llll}
\hline 4. & $\begin{array}{l}\text { Use pictures to understand new or unfamiliar words } \\
\text { when listening. }\end{array}$ & $\mathbf{2 7}$ & $\mathbf{3 5 . 5 2 \%}$ \\
5. & $\begin{array}{l}\text { Take notes when listening to remember the main } \\
\text { idea. }\end{array}$ & $\mathbf{3}$ & $\mathbf{3 4 \%}$ \\
Total & & $\mathbf{7 6}$ & $\mathbf{1 0 0 \%}$ \\
\hline
\end{tabular}

Table 1 above summarizes the frequency of recurrence and inclusion of the listening activities that meet the specific listening outcomes of Action Pack 5. Throughout the textbook, the listening skill comes under different activities i.e. categories: "Listen and Read" "Listen and Answer", "Listen, Ask, and Answer", "Listen and Match", "Listen and Say", "Listen, Choose, and Say", "Listen, Complete, and Say", "Listen and Tick" "Sing".

Starting with criterion number four, which is using pictures to understand new or unfamiliar words when listening, the percentage is $\mathbf{3 5 . 5 2 \%}$. These activities come under the instructions "Listen and Read" and "Listen and Match" of "Listen and Tick" "Listen, Choose, and Say". The activity "Listen and Read", most of the time, is used as the opening of the unit. It is about a story to which students listen or dialogue and both are followed by the texts in pictures. In the other instructions, students listen to a short passage and match it with the correct picture or tick the right answer. Therefore, students learn from these activities new and unfamiliar words, and as they listen, they may pronounce these words. Examples of these activities are all number 1 activities in all the units; in Unit 1 on page 4, Unit 2 on page 8, Unit 3 on page 12, Unit 4 on page 16, Unit 5 on page 20, Unit 6 on page 24, Unit 7 on page 28 , Unit 8 on page 32, Unit 9 on page 36, Unit 10 on page 40, Unit 11 on page 44, Unit 12 on page 48 , Unit 13 on page 52, Unit 14 on page 56, Unit 15 on page 60, Unit 16 on page 64, Unit 17 on page 68, and Unit 18 on page 72.

All of these activities take the form of a four-picture story or a dialogue illustrated through conversations between family members, friends, teachers and pupils and the Units' titles are reflected in such activities. For example, in Unit number 1, activity 1 on page 4, the activity is about going to the park so as students learn about certain words like the park, water park, theme park, playing football, play swings. In Unit 5, activity 1 on page 20, the activity is about going to see planes and words related to it were mentioned such as "transport", "planes", "helicopters", "lorries". In Unit 11, students will learn about meals in which they acquire a number of words related to meals such as onions, cook, lentils, rice, salad, spices, and so on. In Unit 12, activity 1 on page 48, the activity is about going to see animals like "Arabian Oryx", "foxes", "eagle", "ostriches", "wild cats". In Unit 15 for example, the activity is about celebration; students learn about celebration, independence, planes in the sky, national song, flag and so on. For the activities in which students listen and match, examples are found in Unit 3, activity 2 on page 13 in which students listen and try to match the words "friendly, kind, helpful, tidy" with the right picture. In Unit 5, activity 7 on page 23 , students listen and match the right word or expression with the right given picture. Another example is in Unit 10, activity 6 on page 43, in which students listen and tick. Or in Unit 15, activity 2, students, here, listen and choose according to the picture, then say. In all these examples, students learn unfamiliar words listening to them, pronouncing them, and getting grasping their meaning with the assistance of pictures, so as to learn them in context.

Referring to criterion number two, that has the highest percentage $\mathbf{4 3 , 4 2 \%}$ which is responding to questions before, during, and after listening. Actually, all the previous activities which meet the fourth criterion meet also this criterion. Thus, these activities reflect more than one criterion under the instructions "Listen and Read", "Listen and Match", "Listen and Tick", "Listen, Choose, and Say" since students may be asked questions before they listen to the pre-teach vocabulary or elicit the new words from them as they see the pictures. So, students respond before starting to listen. Then, during listening, they may be asked questions and when finishing as well and they may listen for more than once. All the above-mentioned examples illustrate well this criterion. Moreover, there are other activities that meet this criterion. These come under the instructions "Listen and Answer", "Listen, Ask and Answer";" Listen, choose, and Say" in which students listen to passages and respond to questions. Examples are provided in Unit 4, activity 3 on page 17 in which students listen then answer a number of questions after listening. In Unit 6, activity 6 on page 27 , students listen and then choose, and after that they say. So, they respond orally after listening, pointing to the right picture. In Unit 9, activity 4 on page 37, students listen, and they ask questions and then answer. In Unit 11, activity 2 on page 45 , students listen; they complete as they listen and they say at the end. In Unit 13, activity 6 on page 51, students listen and answer. In Unit 15, activity 2 on page 61, students listen, choose and say.

Criterion number one that is the recognition of the different sounds of some consonant Alphabet took a percentage of $\mathbf{1 0 . 5 2 \% . ~}$ Examples on these activities are many starting by Unit 2, activity 5 on page 11, in which students learn the sound /s/ with its different letters. In Unit 3, activity 5 on page 15, students learn the sound /k/ in the words "costume", "kind", and "jacket". In Unit 
5 , activity 5 on page 23 , students learn the consonant /m/ in words "motorbike", "summer", and "lamb". In Unit 8, activity 5 on page 35 , students learn about the sound /dz/ in words like "orange", "juice", and "bridge". More examples are in the subsequent units such as in Unit 10, activity 5 on page 43, in which the sound /b/ is presented in the words "butter", "rubber", and "cupboard". In Unit 14, activity 5 on page 59, the sound /z/ is presented in the words "zoo", "fizzy", "clothes", and "exercise". In Unit 15, activity 5 on page 63 as well.

In some activities as those mentioned, students also learn about vowel sounds, not only consonants, which are included within this criterion. Such examples are in Unit 1, activity 6 on page 7 which is about the diphthong /ei/ as in "plane", "cake", "holiday". In Unit 7, activity 6 on page 31, they learn the long /i:/. Besides, in the activity under "Sing", students sing and pronounce at the same time. This is in Unit 2, activity 7 on page 11 about the /s/ sound in words "circles". In Unit 7, activity 8 on page 31 and in Unit 15, activity 7 on page 63 about the sound /n/ in words "national", "plane" and so on.

Concerning the criterion number three that is showing appreciation to rhymes and songs, there were five activities under the instruction "Sing". These activities incorporate vocabulary and grammar learned in the course, and sounds. Thus, through singing, students enjoy themselves and learn rapidly the rhythms and patterns of English. These activities are illustrated in Unit 1, activity 7 on page 11, Unit 7, activity 8 on page 31, Unit 11, activity 7 on page 47, Unit 15, activity 7 on page 63 and In Unit 17, activity 6 on page 71 .

With regards to the last criterion that is taking notes when listening to remember the main idea, it showed a percentage of 3.94\%. In this activity, students listen to an informational text about the oak tree in Jordan. This activity is illustrated in Unit 12 , exercise 6 on page 51.

\section{Conclusion}

This content analysis attempted to examine whether the listening activities in Action Pack 5 agree with the specific outcomes of this skill. The findings of this analysis highlighted the strengths and weaknesses. Upon the analysis of the listening activities of Action Pack 5, the researchers found that the most frequent criteria are as follows: responding to questions before, during, and after listening to the questions, using pictures in order to learn new words and recognition of Alphabet sounds. These are crucial for the development of the listening skill since listening organizers entail that students should learn sounds, learn words in which these sounds are presented and pronounce them accurately. Yet, the highest percentage $43.42 \%$ goes with responding to questions before, during and after listening, followed by $35.52 \%$ using pictures to understand new or unfamiliar words when listening. For the criterion which shows appreciation to rhymes and songs it appeared in, $6.6 \%$ of 5 frequency. Therefore, students will not get bored or lose interest and this ensures the efficiency of the learning process. For the "note taking when listening to remember the main idea", the researchers believe that it is a beneficial criterion that students have to administrate and more exercises should be included because it helps a lot in the comprehension process; it trains students how to listen and take the most important ideas so as to grasp the meaning. In the end, based on the findings of this analysis, it can be concluded that the inclusion and presentation of the listening activities in Action Pack 5 is relatively appropriate according to the analyzed listening exercises mentioned in the textbook. In addition, the listening activities in the units of the textbook are presented and distributed equally. There are also varied listening activities in the textbook. Such variety assists students to develop their language competence. Moreover, the selection of the listening activities was meaningful and suitable. Such selection helps to integrate the listening activities with other language skills since it facilitated EFL students' language learning. Furthermore, the study revealed that the listening activities correspond to the specific outcomes related to the listening organiser in the General Guidelines.

Funding: This research was funded by the researchers.

Acknowledgments: I would like to thank Mr. Suleiman Al-Zoubi (An EFL Teacher / The Ministry of Education) and Hydayah Jobran Al-Roumi (A Ph.D. student in Queensland University) for their assistance in the study.

Conflicts of Interests: The authors declare no conflict of interests.

\section{References}

[1] Al-Ghazo, A. \& Smadi, O. (2013). A Content Analysis of the English Reading Text's Authenticity in Student's Book of Action Pack Eleven in Jordan. European Scientific Journal, 9(29). 342-359.

[2] Assaly, I., \& Igbaria, A. (2014). A Content Analysis of the Reading and Listening Activities in EFL Textbook of Master Class. Education Journal, 3(2), 22-38. Doi:10.11648/j.edu.20140302.11

[3] Brown, H.D. (2001). Teaching by principles: An interactive approach to language pedagogy. On Francisco: State University.

[4] Brown, S. (2006). Teaching Listening. Cambridge University Press.

[5] Dugassa, G. \& Mijena E. (2014). Analysis of the Design of Grade 9 Listening Lessons in the Student's Book and Teacher's Guide of English of Ethiopia. Science, Technology and Arts Research Journal. 3(4). 201-206. Doi: http://dx.doi.org/10.4314/star.v3i4.29

[6] Elo, S. \& Kyngas, H. (2007). The Qualitative Content Analysis Process. Journal of Advanced Nursing ,62(1),107-117. 
[7] Holsti, O, K. (1969). Content analysis of the social sciences and humanties, reading, massachusetts: Addison Wisely Publishing Company.

[8] Huei-Chun, T. (1998). A Study of EFL Listening Comprehension Strategies. Eric. 1-19.

[9] Keban, N.V., Muhtar, A., \& Zen, E. L. (2011). A Content Analysis on English For Kids Grade 3, A Textbook used in Elementary Schools in Malang. Malang: State University of Malang. URL:

https://www.academia.edu/29053380/A CONTENT ANALYSIS ON ENGLISH FOR KIDS GRADE 3 A TEXTBOOK USED IN ELEME NTARY SCHOOLS IN MALANG

[10] Krippendorf, K. (1980). Content analysis: An introduction to its methodology. Beverly Hills, CA: Sage.

[11] Manasrah, M, A., Al-Sobh, M., A., \& Al-Jabali, M., A. (2013). A content Analysis of the Vocabulary Items in "Action Pack 12" for Twelfth Grade in the Jordanian Schools. International Journal of Humanities and Social Sciences, 3(15). $129-136$. Retrieved from http://www.ijhssnet.com/journals/Vol 3 No 15 August 2013/15.pdf

[12] Ministry of Education. (1991). English Language Curriculum and its General Guidelines for the Basic and Secondary Stage. Amman. Jordan.

[13] Ministry of Education. (2006). General Guidelines and General and Specific Outcomes for English Language. Amman. Jordan.

[14] Mizbani, M. \& Chalak, A. (2017). Analyzing Listening and Speaking Activities of Iranian EFL Textbook 3 Through Bloom's Revised Taxonomy. Advances in Language and Literacy Studies, 8(3). 38-44. Doi:10.7575/aiac.alls.v.8n.3p.38

[15] Omaggio, A.(2001). Teaching language in context. New York: Heinle \& Heinle.

[16] Taamneh, I., M. (2018). Analyzing the Listening Activities That Match the Listening Specific Outcomes in the Jordanian Guidelines for the Pupil's Book of Action Pack 5. International Research in Education. 6(1). 50-62. doi:10.5296/ire.v6i1.12657

[17] Tyagi, B. (2013). Listening: An Important Skill and Its Various Aspects. The Criterion An International Journal in English. $12,1-8$. 